\title{
THE ROLE OF SUPPORT ON START-UP SUCCESS: A PLS-SEM APPROACH
}

\author{
Daisy Mui Hung Kee ${ }^{1 *}$, Yusmani Mohd Yusoff ${ }^{2}$, and Sabai Khin' ${ }^{1}$ \\ ${ }^{1}$ School of Management, Universiti Sains Malaysia, 11800 USM Pulau Pinang, Malaysia \\ ${ }^{2}$ School of Business Management, Universiti Utara Malaysia, 06010 UUM Sintok, \\ Kedah, Malaysia \\ *Corresponding author: daisy@usm.my
}

Published online: 20 March 2019

To cite this article: Kee, D.M.H., Yusoff, Y.M., and Khin, S. (2019). The role of support on start-up success: A PLS-SEM approach. Asian Academy of Management Journal, 24(Supp. 1), 43-59. https://doi.org/10.21315/aamj2019.24.s1.4

To link to this article: https://doi.org/10.21315/aamj2019.24.s1.4

\begin{abstract}
A start-up plays a significant role in the economic growth, employment opportunity, incubators for eco-innovation, and create a new market. Despite their important roles towards the economic and social growth, start-ups face difficulty in sustaining and surviving as the failure rate of start-up range between $50 \%$ and $95 \%$, especially in emerging countries such as Malaysia. Therefore, it is important for start-ups in developing countries to identify specific support services that determine their success. In this study, we focus on technology-related, market-related, finance-related, and soft-related supports received by start-ups in Malaysia. The present study has collected data from 500 startups in Malaysia who were recipients of the funding from Malaysia government agencies. To the best of our knowledge, this study provides the first statistical test of how start-ups who were business owners or business partners receiving funding or support from the government agencies view the support system. Based on the analysis, this study provides evidence that support matters to start-up success. Technology-related, finance-related, and soft-related supports hold a significant relationship with the start-up success, while surprisingly, market-related support did not have a significant relationship with start-up success. Our results have extended previous research by highlighting the importance of these supports in driving start-up success and indicating how each dimension of these support services either enhances or inhibits start-up success.
\end{abstract}

Keywords: start-up success, technology-related support, financial-related support, marketrelated support, soft-related support

(C) Asian Academy of Management and Penerbit Universiti Sains Malaysia, 2019. This work is licensed under the terms of the Creative Commons Attribution (CC BY) (http://creativecommons. org/licenses/by/4.0/). 


\section{INTRODUCTION}

Start-ups bring lots of advantages to the nation such as increasing economic development, offering employment opportunities, and creating innovation (Bøllingtoft, 2012; Giardino, Unterkalmsteiner, Paternoster, Gorschek, \& Abrahamsson, 2014). Other than that, start-ups are important to the society as they will help to overcome social issues such as income inequalities and poverty (Thirlwall, 2011) as well as vital for nation growth (Surienty, Khoo, \& Kee., 2011). In line to that, several studies have been conducted to investigate the impact of start-ups on economic growth, job creation as well as wealth creation (e.g., Acs, Desai, \& Hessels, 2008; Ahmad \& Xavier, 2012; Carree \& Thurik, 2003).

Due to the vital role of start-ups in the national economic development agenda, the government realised the need to develop start-ups and ensure their success as several challenges and obstacles confront start-ups (Tengeh \& Choto, 2015). Also, start-ups can hardly survive. In the global industry, start-ups contributed $39 \%$ of the total revenue. However, start-ups face challenges and difficulties in sustaining and surviving as the failure rate range between $50 \%$ to $95 \%$, especially in emerging countries such as Malaysia. Organisation for Economic Co-operation and Development (OECD, 2000) reported that less than 50\% of start-ups survive for more than five years. According to Giardino et al. (2014), approximately $60 \%$ of start-up businesses fail in their first five years of businesses. Hence, the first five years is the most vulnerable period for a start-up business. They are facing with key challenges and obstacles such as lack of awareness in terms of resources, lack of information in terms of business opportunities, inadequate networking, and absence of business supports (Aggarwal, 2012; Kee, Effendi, Talib, \& Rani, 2011). Start-ups are categorised by the insufficiency of resources and are regularly failing to perform or growth (Cohan, 2012).

Concurrently, with this recognition of the economic importance of start-ups, there are findings that start-ups are fragile. Therefore, it is important for startups in developing countries to identify if support predictive of their success. The appropriate ecosystem is needed to increase the survival of start-ups. To achieve success, the start-ups would require to carefully assess their decision and options to identify what is critical for the survival of the businesses. They should be aware of the support in the ecosystem to increase the success and survival rate. Start-ups can exploit the access to the ecosystem to identify new market opportunities, develop modern technology, access funding, and gain legitimacy (Pettersen, Aarstad, Høvig, \& Tobiassen, 2015; Sullivan \& Marvel, 2011). Furthermore, in developing countries such as Malaysia, there is a lack of empirical evidence that investigates the determinants of a start-up, although past studies have been conducted on the 
issues of how entrepreneurship, especially during their start-up period, affects the economy (Iakovleva, Kolvereid, \& Stephan, 2011). In this paper, we intend to examine how does support (financial-, technology-, market-, and soft-related supports) help in the start-up success.

Evaluating the start-up ecosystem requires an examination of many factors that influence the ability to launch and operate start-ups in Malaysia successfully. Therefore, understanding the ecosystem of the start-ups in Malaysia would allow the policymakers to use this information to formulate policies that are modified for the fundamental of national economic growth (Abu Bakar, Ahmad, Wright, \& Skoko, 2017). In most of the developed countries, the government play a vital role to the growth of start-ups (Abu Bakar et al., 2017) such as introducing subsidised or partly subsidised programmes for start-up (Yusuf, 2014). According to Yusuf (2010), a substantial volume of public resources is provided to support and assist start-ups. However, many start-ups fail to identify the challenges and obstacles of the business process and incapable of reaching successful results (Yusuf, 2014). Hence, government involvement is claimed to lessen the high failure rates of start-ups (Deakins, Sullivan, \& Whittam, 2000). Therefore, the government have formed assistance programmes to support start-up businesses to overcome these challenges and obstacles (Yusuf, 2014). Support in some countries such as the United States helps to enhance the start-up success, growth, performance, and survival (Yusuf, 2014). In addition, there are many supports from various agencies in the development of start-up. However, there is a lack of understanding of what kind of support services needed by start-ups (Henry, 2017).

Therefore, it is essential to understand the specific support that determines the success of start-ups in developing countries. To determine the support of the startups, the understanding of the ecosystem of the start-up is fundamental, especially on identifying the role of support systems such as technology-related support services, market-related support services, finance-related support services, and soft-related support services (Heydebreck, Klofsen, \& Maier, 2000). We examine how the role of these supports (technology-, market-, finance-, and soft-related supports) can significantly impact the success of start-ups in Malaysia.

\section{LITERATURE REVIEW}

\section{Start-up Success}

Start-ups help to form more employment opportunity than large and established businesses, governments, and private sectors have promoted start-up businesses 
and reduced the events of their failures (Carter \& Auken, 2006; Savlovschi \& Robu, 2011). Sharifi and Hossein (2015) defined a start-ups business as a young business that is opening its operations and is designed to grow into large firms (Blank, 2012). Also, Pickernell, Senyard, Jones, Gary, and Ramsey (2013) defined start-up businesses as young and new businesses as existing below four years. This study defined start-up success as the ability of a firm to survive or to sustain in business based on financial and non-financial performance for the past five years (Durda \& Krajcik, 2016; Lussier \& Pfeifer, 2001; Yaacob, Mahmood, Mat Zin, \& Puteh, 2014).

Some extensive studies about the factors that influence the success of start-up businesses have been developed because start-up contributed significant effects towards the society such as solving employment issues, enhancing economic stability, and balancing income distribution among the society (Hashim, 1999). However, identifying and measuring start-up success is relevantly difficult as it is a relative measure. Start-up success can be measured in various ways such as financial, non-financial, or hybrid method (Durda \& Krajcik, 2016; Lussier \& Pfeifer, 2001; Yaacob et al., 2014).

In a study carried out by Omri, Frikha, and Bouraoui (2015), they measured business performance based on profitability. Hence, profitability is one of the significant performance measurement for business, especially for a start-up business. Another study by Fisher, Maritz, and Lobo (2014) found that entrepreneurs measure their business success based on their incessantly business growth. On the other hand, Lussier and Halabi (2010) suggested using non-financial measurement to measure the success of start-up business, as the non-financial measurement is more appropriate since start-up business does not have proper financial accounting data. Furthermore, start-up businesses may not have a proper report in terms of their sales and profits as they do not keep records properly (Gerba \& Viswanadham, 2016). However, Gerba and Viswanadham (2016) suggested using a hybrid approach when measuring start-up success. Hybrid measures include both financial and nonfinancial measurement of performance that usually incorporate multi-dimensional aspect to overcome drawbacks of a single measure of performance. Thus, Gerba and Viswanadham (2016) proposed the financial and non-financial measures of start-up business performance comprise of total assets, profitability, sales volume, return on investment (ROI), capital employed, market share, the total number of employees, employees' turnover, customer satisfaction, productivity, and delivery time. 


\section{Support Services}

A study conducted by Brooksbank (2008) found that in the start-up ecosystem, the government is the significant player that promote the success of start-up businesses. Curran and Storey (2002) stated that some of the government support services included direct advice services and formal support such as identifying business activities, training, market research, advertising, and innovative technology (Bennet \& Robson, 2003). However, the lack of government support towards startup has contributed to its failure in Malaysia scenarios (Saleh \& Ndubisi, 2006). However, Kee et al. (2011) had a different point of view and argued that the key issue is not related to the lack of government support, but the accessibility of the support programme itself. $\mathrm{Ng}$ and Kee (2017) added that most SMEs often struggle to keep on top of new development and encounter problems in their operation and it is inevitable that government must intervene in SMEs development by providing infrastructure and financial grants. Kee et al. (2011) found that most of the SMEs relied on private sponsors or self-funding to get financial support, penetrate new markets and search for customers as they did not receive the full range of assistance due to the complicated procedure of financing application.

Undeniably, Malaysian government has provided numerous supports to startups. For example, Malaysian government has executed the programmes that focused on financing, technology transfer, and infrastructure development in 2012 (SME Corp., 2014). In addition, Malaysian government has executed a total of 139 financial programmes for start-ups in 2013, while with the collaboration with private sector, the government has also executed another 15 programmes amounting to RM8.5 billion (SME Corp., 2014). In 2010, SME Corporation implemented 269 programmes (amounted to RM6.9 billion), and the majority is allocated to enhance the access of start-up businesses in financing (SME Corp., 2014). In addition, numerous training programmes are held, such as 1-InnoCert certification to improve innovation capacity of start-up businesses; SME Competitive Rating for Enhancement (SCORE) system which is a tool to assess and rate the competitiveness of start-up businesses based on company capabilities and performance; university internship to support entrepreneurial culture; and the National Mark-of-Malaysia Brand certification to increase the promotion products/ services of start-up businesses (SME Corp., 2018).

However, there is a limited understanding of how, what, and which programmes and policies from the government that help in promoting and supporting start-ups (Audretsch, 2004). For example, most of the start-ups in Malaysia face difficulties in gaining financial supports due to deficiency of collateral and inadequate documents to support their loan application (Haron, Said, Jayaraman, \& Ismail, 
2013). Financial support is needed by start-up to set-up the business, enhance their production, and to recruit employees (Haron et al., 2013). According to Beck and Demirguc-Kunt (2006), start-up experienced complex financing obstacles than larger and established businesses. Finance-related services refer to the support in accessing external financing sources such as venture capital funds and direct financial support and many more (Dwivedi \& Mishra, 2013; Heydebreck et al., 2000). Finance-related is defined as monetary support to the start-up, from the government and institution owned by the government such as support schemes, mediation of contacts to financiers, and direct support in the financing of innovation projects which entrepreneurs take while starting their business or enhancing the business (Alfredsson, 2003; Dwivedi \& Mishra, 2013; Heydebreck et al., 2000). The government must improve finance-related services by enhancing the access of start-up businesses to finance needs to help them develop and grow. According to SME Masterplan, most of the start-up businesses in Malaysia stated that they are facing the lack of accessibility to funding institutions and it takes long time for the small number of loans because of this obstacle (SME Corp., 2015). Financial funding can be termed to be the significant factor of any established company especially for start-up business as it determines a substantial part of the business performance and financial support contributes to $25 \%$ of the small business success (Akinruwa, Awolusi, \& Ibojo, 2013). It is also supported by Kee et al. (2011) that the key issues faced by SMEs are lack of consultation through an informal network, communication of policies to local, and identifying economic development opportunities. Kee added that even though these supports are provided by the government, it appears that SME is facing difficulties in accessing the government support. Based on the above discussion, the following hypothesis is formulated:

H1: Finance-related support has a positive impact on start-up success.

On the other hand, the majority of start-up failure was due to the inability to recognise and respond to high-value market opportunities and a failure to take fast action when opportunities were identified, and being under-prepared (Ahmad $\&$ Seet, 2009). In addition, Temtime and Pansiri (2004) found that poor customer service, lack of proper study in the marketing process, and inadequate analysis in terms of demand and supply are also the issues that related to start-up failure. For start-up businesses to commercialise their products/services, they must have ample business and market-related knowledge (McKelvey \& Lassen, 2013). Thus, start-up businesses frequently need consultancy in marketing, searching and analysing the potential market, and searching for business partners to cater for this failure (Heydebreck et al., 2000). Start-up businesses need market-related services as such consultancy in marketing, assist with marketing of products and technologies, provision of a customer, supplier network, opportunities in the 
market, commercialisation and distribution such as trade shows and exhibitions (Heydebreck et al. 2000; Kaufmann \& Tödtling, 2002). In this study, marketrelated services are defined as support services that consist of assistance in the marketing of products and technologies, a search for customers and suppliers, and assistance with new products launches (Heydebreck et al., 2000). Therefore, the following hypothesis is proposed:

H2: Market-related support has a positive impact on start-up success.

Another support service that plays a significant role in start-up success is technology-related services. Technology-related services such as technology transfer will improve innovations among start-up businesses (Intarakumnerd \& Ueki, 2009). Technology-related services through the collaboration among private agencies, public agencies, industry, and universities will help to enhance processes and method of the operation and business activities (SME Corp., 2014). Technology-related services include foster technology collaboration to form research and development (R\&D) that focused on promoting the business network, commercialisation of knowledge, financial incentives such as $R \& D$ grants and levies for technology development, and promoting technology distribution (Gill \& Kharas, 2015). This study defines technology-related services as the availability of technology support for the execution and management of $R \& D$, technological consultancy, search for R\&D cooperation partners, and availability of providing infrastructure to create a conducive environment for the growth of the start-up business (Akinruwa et al., 2013; Heydebreck et al., 2000). However, in the context of Malaysia, Malaysian entrepreneurs facing limited capability to access and acquire them (Kiatgan \& Almsafir, 2013). This happened due to the start-up businesses are frequently obstacle by their inadequate capital for their business development of technology adoption (Zulkifli-Muhammad, Char, Yasoa, \& Hassan, 2010). Thus, the hypothesis is proposed:

H3: Technology-related support has a positive impact on start-up success.

A study carried out by Heydebreck et al. (2002) identified soft services as key areas for the support that government provides especially for a start-up business. Malaysia government through the 10th Malaysia Plan (2011-2015) is concentrating on the six national key economic areas (NKEAs), to promote knowledge-intensive and innovation-led economy growth. Hence, soft-related support services such as networking, mentoring, raising awareness, education, training, consultancy, problem-solving skills, and acquiring learning capabilities (Falk, 2007; Heydebreck et al., 2000) as significant factors for start-up success. Based on a study by Bosma, Van Praag, Thurik, and De Wit (2004), they found 
that start-up businesses will have more success when they invested in soft skills such as training and information gain from networking and consulting when starting the business. In addition, training programmes for start-up business have a positive effect on the start-up success (Jansen \& Weber, 2004). In this study, soft-related service is defined as general types of support, comprising seminars and information provision, education and teaching programmes, and consulting. These services typically assist the start-up businesses in developing a network, and in enhancing their know-how (Heydebreck et al., 2000), hence, the hypothesis is proposed:

H4: Soft-related support has a positive impact on start-up success.

\section{METHODOLOGY}

Data were collected from the targeted respondents, who are the business owners of 500 start-up firms that were established between 2012 to 2016 located in Malaysia. Only those respondents who were business owners or business partners receiving funding or support from the government or agencies were included in the study. Most of the respondents (39.4\%) fall in the age group of 41-50 followed by $31-40$ $(36.2 \%)$. More than half of the respondents were male (58.8\%), and the remaining were female $(41.2 \%)$ as business has always been a male-dominating profession. This figure also reflects a steady exponential growth in women entrepreneurship in Malaysia. Most of the respondents were business owners (60.6\%) and the remaining (39.4\%) were business partners. Majority of the respondents formed the companies in 2013 (34.8\%), followed by 2012 (27.6\%), 2014 (21.8\%), 2015 (13\%), and $2016(2.8 \%)$. For business activity, $62.8 \%$ of the businesses were from the services sector, and $37.2 \%$ were from the manufacturing sector.

Start-up success was measured using nine items adapted from Yaacob et al. (2014), Yankov, Ruskov, and Haralampiev (2014), and Weber and Zulehner (2010). The start-up success measure consists of profitability, growth, reach intended goals, survival, customer satisfaction, personal satisfaction, networking, reputation/ business image, and an increase in the number of employees. The respondents were asked to indicate their businesses' performance relative to their major competitors over the past 12 months. Each dimension of start-up success was measured on a 5-point Likert scale, ranging from 1 (significantly lower) to 5 (significantly better). To measure finance ( 6 items), market ( 7 items), technology (9 items), and soft-related support (10 items), Heydebreck et al. (2000) and Knockaert, Vandenbroucke, and Huyghe (2012)'s scales were adapted. Each dimension of support was measured on a 7-point Likert scale, ranging from 1 (inaccessible) to 
7 (extremely accessible). To test the hypotheses generated, we employed Smart PLS Software to analyse the data. We used the bootstrapping method $(5,000$ resamples) to determine the significance levels for loadings and path coefficients.

\section{RESULTS}

This study used the two-step approach as suggested by Anderson and Gerbing (1988). Firstly, the study assessed convergent validity, reliability, and the discriminant validity. Convergent validity can be ascertained if the loadings are greater than 0.5 (Hair, Black, Babin, \& Anderson, 2010), composite reliability greater than 0.7 (Gefen, Straub, \& Boudreau, 2000), and the average variance extracted is greater than 0.5 (Fornell \& Larcker, 1981). This study also tested for the discriminant validity using the evaluation of the heterotrait-monotrait ratio of correlations (HTMT) (Henseler, Ringle, \& Sarstedt, 2015). Using HTMT as a criterion to access discriminant validity, the researcher needs to compare it to a predefined threshold. Hence, if the value of the HTMT is greater than it predefined threshold, the researcher can conclude that there is non-existence of discriminant validity. This study used a conservative threshold of 0.85 as suggested by Clark and Watson (1995) and Kline (2015). Table 1 demonstrates the results of the measurement model while Table 2 shows the results of discriminant validity. The structural model was tested next. $\mathrm{R}^{2}$ is 0.705 which meant that $70.5 \%$ of the variance in start-up success performance was explained by the finance-related services, market-related services, technology-related services, and soft-related services. Table 3 summarises the findings of all the research hypotheses developed for this study. The hypothesised direct relationships were assessed based on the path analysis.

Table 1

Results of measurement model

\begin{tabular}{lcccc}
\hline Model construct & Measurement item & Loading & CR & AVE \\
\hline Finance & Fin_DA1 & 0.582 & 0.876 & 0.591 \\
& Fin_DA2 & 0.675 & & \\
& Fin_DA3 & 0.822 & & \\
Fin_DA4 & 0.880 & & \\
Market & Mar_DA1 & 0.935 & 0.959 & 0.771 \\
& Mar_DA2 & 0.821 & & \\
& Mar_DA3 & 0.749 & & \\
& Mar_DA4 & 0.917 & & \\
\hline
\end{tabular}

(continued on next page) 
Daisy Mui Hung Kee et al.

Table 1 (continued)

\begin{tabular}{lcccc}
\hline Model construct & Measurement item & Loading & CR & AVE \\
\hline \multirow{5}{*}{ Technology } & Mar_DA5 & 0.863 & & \\
Mar_DA6 & 0.958 & & \\
Mar_DA7 & 0.884 & & \\
Tech_DA1 & 0.702 & 0.911 & 0.563 \\
Tech_DA2 & 0.672 & & \\
Tech_DA3 & 0.757 & & \\
Tech_DA4 & 0.793 & & \\
Tech_DA5 & 0.746 & & \\
Tech_DA6 & 0.755 & & \\
Tech_DA8 & 0.808 & & \\
Tech_DA9 & 0.761 & & \\
Soft & Soft_DA1 & 0.946 & 0.932 & \\
Soft_DA2 & 0.957 & & \\
Soft_DA4 & 0.737 & & \\
Soft_DA8 & 0.737 & & \\
Soft_DA9 & 0.789 & & \\
Soft_DA10 & 0.823 & & \\
\hline
\end{tabular}

Note: Fin_DA5, Fin_DA6, Tech_DA7, Soft_DA3, Soft_DA5, Soft_DA6, and Soft_DA7 were deleted due to low loadings of $<0.50$. A $\bar{V} E=$ average variance extracted; $\overline{C R}=$ composite reliability

Table 2

Discriminant validity of constructs

\begin{tabular}{lccccc}
\hline & Finance & Market & Soft & Technology & Start-up success \\
\hline Finance & & & & & \\
Market & 0.202 & & & & \\
Soft & 0.483 & 0.281 & & & \\
Technology & 0.829 & 0.271 & 0.457 & & \\
Start-up success & 0.554 & 0.273 & 0.315 & $\mathbf{0 . 5 4 7}$ & \\
\hline
\end{tabular}


Table 3

Path coefficients and hypothesis testing

\begin{tabular}{llcccl}
\hline Hypothesis & Relationship & $\begin{array}{c}\text { Direct } \\
\text { effect }\end{array}$ & $t$-statistic & $p$-value & Result \\
\hline H1 & Finance $\rightarrow$ Start-up success & 0.380 & $4.480^{* *}$ & 0.000 & Supported \\
H2 & Market $\rightarrow$ Start-up success & 0.060 & 0.454 & 0.650 & Not supported \\
H3 & Technology $\rightarrow$ Start-up success & 0.357 & $4.317^{* *}$ & 0.000 & Supported \\
H4 & Soft $\rightarrow$ Start-up success & 0.115 & $1.892^{*}$ & 0.059 & Supported \\
\hline
\end{tabular}

Note: $t$-values $>2.33 ;{ }^{* *}$ significant at $p<0.01 ; t$-values $>1.645 ;{ }^{*}$ significant at $p<0.05$

\section{DISCUSSION AND CONCLUSION}

This study investigated the specific support (technology-related, finance-related, market-related, and soft-related) that determine the success of start-up. The results of this study showed that finance-related, technology-related, and soft-related supports have a significant impact on the start-up success in Malaysia. It highlights that in the context of Malaysia, these supports help start-up to sustain and succeed. Finance-related support appears to be the most critical resources for start-up growth and survival. This may be due to its nature that finance-related support provides interventions that effectively protect start-up. It acts as a buffer, allows start-up to engage in developmental activities without having to confront directly to the potential threats. Technology-related support appears to be the second important predictor of start-up success followed by soft-related support. On the other note, market-related support does not appear to be a good predictor to influencing startup success in Malaysia. This may be due to the fact that as compared to marketrelated support, the other three supports stand out as a stronger positive predictor of start-up success. Another possible explanation is it could be due to the low accessibility of the market-related support. Therefore, Malaysian government should focus on building awareness and examining accessibility about numerous programmes related to market-related support that provided by various agencies such as Malaysian Automotive Institute, Malaysian External Trade Development Corporation (MATRADE), SME Corporation, and Federal Agriculture Marketing Authority (FAMA). Marketing strategies are of utmost importance for start-up to reach their customers, hence government should develop strategies in terms of accessibility of these supports. In conclusion, the key point that emerged from the study is that start-up needs a model that captures holistically all the aspects that contribute towards start-up success or failure. 


\section{ACKNOWLEDGEMENTS}

The authors would like to thank Malaysian Technology Development Corporation for providing the research grant (grant number: 304/PMGT/650877/M130).

\section{REFERENCES}

Abu Bakar, A.R., Ahmad, S.Z., Wright, N.S., \& Skoko, H. (2017). The propensity to business startup: Evidence from Global Entrepreneurship Monitor (GEM) data in Saudi Arabia. Journal of Entrepreneurship in Emerging Economies, 9(3), 263-285. https://doi.org/10.1108/JEEE-11-2016-0049

Acs, Z., Desai, S., \& Hessels, J. (2008). Entrepreneurship, economic development and public policy. Small Business Economics, 31(3), 219-234. https://doi.org/10.1007/ s11187-008-9135-9

Aggarwal, R. (2012). Research on the state of business incubation system in Rwanda: Lesson for African countries. Journal of US-China Public Administration, 9(6), 707-717.

Ahmad, N.H., \& Seet, P. (2009). Dissecting behaviours associated with business failure: A qualitative study of SME owners in Malaysia and Australia. Asian Social Science, 5(9), 98-104. https://doi.org/10.5539/ass.v5n9p98

Ahmad, S.Z., \& Xavier S.R. (2012). Entrepreneurial environments and growth: Evidence from Malaysia GEM data. Journal of Chinese Entrepreneurship, 4(1), 50-69. https://doi.org/10.1108/17561391211200939

Akinruwa, T.E., Awolusi, O.D., \& Ibojo, B.O. (2013). Determinants of small and medium enterprises (SMEs) performance in Ekiti State, Nigeria: A business survey approach. European Journal of Humanities and Social Sciences, 27(1), 13921406.

Alfredsson, L. (2003). Financial and non-financial support in the aero engine industry. Masters dissertation, Lulea University of Technology.

Anderson, J.C., \& Gerbing, D.W. (1988). Structural equation modelling in practice: A review and recommended two-step approach. Psychological Bulletin, 103(3), 411-423. https://doi.org/10.1037/0033-2909.103.3.411

Audretsch, D. (2004). Sustaining innovation and growth: Public policy support for entrepreneurship. Industry and Innovation, 11(3), 167-191. https://doi.org/10. 1080/1366271042000265366

Beck, T., \& Demirguc-Kunt, A. (2006). Small and medium-size enterprises: Access to finance as a growth constraint. Journal of Banking \& Finance, 30(11), 29312943. https://doi.org/10.1016/j.jbankfin.2006.05.009

Bennett, R. \& Robson, P. (2003). Changing use of external business advice and government supports by SMEs in the 1990s. Regional Studies, 37(8), 795-811. https://doi.org/ $10.1080 / 0034340032000128721$

Blank, S. (2012). The startup owner's manual: The step-by-step guide for building a great company. California: K\&S Ranch Inc. 
Bøllingtoft, A. (2012). The bottom-up business incubator: Leverage to networking and cooperation practices in a self-generated, entrepreneurial-enabled environment. Technovation, 32(5), 304-315. https://doi.org/10.1016/j.technovation.2011.11. 005

Bosma, N., Van Praag, M., Thurik, R., \& De Wit, G. (2004). The value of human and social capital investments for the business performance of startups. Small Business Economics, 23(3), 227-236. https://doi.org/10.1023/B:SBEJ.00000 32032.21192 .72

Brooksbank, D. (2008). Small business policy and support. Environment and Planning C: Government and Policy, 26(2), 287-291. https://doi.org/10.1068/c2602ed

Carree, M., \& Thurik, A., (2003). The impact of entrepreneurship on economic growth. In D. Audretsch, \& Z. Acs (Eds.), Handbook of entrepreneurship research (pp. 437-471). Boston/Dordrecht: Kluwer Academic.

Carter, R., \& Auken, H.V. (2006). Small firm bankruptcy. Journal of Small Business Management, 44(4), 493-512. https://doi.org/10.1111/j.1540-627X.2006.00187.x

Clark, L.A., \& Watson, D. (1995). Constructing validity: Basic issues in objective scale development. Psychological Assessment, 7(3), 309-319. https://doi.org/ 10.1037/1040-3590.7.3.309

Cohan, P.S. (2012). Hungry start-up strategy: Creating new ventures with limited resources and unlimited vision. Berrett-Koehler Publishers.

Curran, J. \& Storey, D.J. (2002). Small business policy in the United Kingdom: The inheritance of the small business service and implications for its future effectiveness. Environment and Planning C: Government and Policy, 20(2), 163-177. https://doi.org/10.1068/c0113

Deakins, D., Sullivan, R., \& Whittam, G. (2000). Developing business start-up support programmes: Evidence from Scotland. Local Economy, 15(2), 159-167. https://doi.org/10.1080/02690940050122703

Durda, L., \& Krajcik, V. (2016). The role of networking in the founding and development of start-up technology companies. Polish Journal of Management Studies, 14(2), 28-39. https://doi.org/10.17512/pjms.2016.14.2.03

Dwivedi, N.T., \& Mishra, T. (2013). Women-empowerment through women entrepreneurship: A study of Faizabad zone of Uttar-Pradesh. Voice of Research, 2(2), 50-55.

Everett, J., \& Watson, J. (1998). Small business failure and external risk factors. Small Business Economics, 11(4), 371-390. https://doi.org/10.1023/A:1008065527282

Falk, R. (2007). Measuring the effects of public support schemes on firms' innovation activities: Survey evidence from Austria. Research Policy, 36(5), 665-679. https://doi.org/10.1016/j.respol.2007.01.005

Fisher, R., Maritz, A., \& Lobo, A. (2014). Evaluating entrepreneurs' perceptions of success: Development of a measurement scale. International Journal of Entrepreneurial Behaviour and Research, 20(5), 478-492. https://doi.org/ 10.1108/IJEBR-10-2013-0157 
Fornell, C., \& Larcker, D.F. (1981). Structural equation models with unobservable variables and measurement error: Algebra and statistics. Journal of Marketing Research, 382-388. https://doi.org/10.2307/3150980 and https://doi.org/10. $1177 / 002224378101800313$

Gefen, D., Straub, D., \& Boudreau, M.C. (2000). Structural equation modelling and regression: Guidelines for research practice. Communications of the Association for Information Systems, 4(7), 2-59.

Gerba, Y.T., \& Viswanadham, P. (2016). Performance measurement of small-scale enterprises: Review of theoretical and empirical literature. International Journal of Applied Research, 2(3), 531-535.

Giardino, C., Unterkalmsteiner, M., Paternoster, N., Gorschek, T., \& Abrahamsson, P. (2014). What do we know about software development in startups? IEEE Software, 31(5), 28-32. https://doi.org/10.1109/MS.2014.129

Gill, I.S., \& Kharas, H. (2015). The middle-income trap turns ten. Policy Research Working Papers (No. WPS 7403). Washington, DC: World Bank Group. https://doi.org/10.1596/1813-9450-7403

Hair, J.F., Black, W.C., Babin, B.J., \& Anderson, R.E. (2010). Multivariate data analysis: A global perspective (7th ed.). Upper Saddle River, NJ: Pearson Education.

Haron, H., Said, S., Jayaraman, K., \& Ismail, I. (2013). Factors influencing small medium enterprises (SMEs) in obtaining loan. International Journal of Business and Social Science, 4(15), 182-195.

Hashim, M.K. (1999). A review of the role of SMEs in the manufacturing sector in Malaysia. Malaysian Management Review, 34(1), 40-49.

Henry, P (2017). Why some startups succeed (and why most fail). Entrepreneur Asia Pacific. Retrieved 20 September 2018 from https:/www.entrepreneur.com/ article/288769.

Henseler, J., Ringle, C.M., \& Sarstedt, M. (2015). A new criterion for assessing discriminant validity in variance-based structural equation modelling. Journal of the Academy of Marketing Science, 43(1), 115-135. https://doi.org/10.1007/ s11747-014-0403-8

Heydebreck, P., Klofsten, M., \& Maier, J.C. (2000). Innovation support for new technologybased firms: The Swedish Teknopol approach. $R \& D$ Management, 30(1), 89-100. https://doi.org/10.1111/1467-9310.00160

Iakovleva, T., Kolvereid, L., \& Stephan, U. (2011). Entrepreneurial intentions in developing and developed countries. Education and Training, 53(5), 353-370. https://doi.org/10.1108/00400911111147686

Intarakumnerd, P., \& Ueki, Y. (2009). Fostering production and science and technology linkages to stimulate innovation in Asean. ERIA Research Project Report, 7, $1-496$.

Jansen, D., \& Weber, M. (2004). Helping hands and entrepreneurship-supporting newly founded firms. In M. Dowling, J. Schmude, \& D. Knyphausen-Aufsess (Eds.), Advances in interdisciplinary European entrepreneurship research (pp. 57-59). New Brunswick, NJ: Transaction Publishers. 
Kaufmann, A. \& Tödtling, F. (2002). How effective is innovation support for SMEs? An analysis of the region of Upper Austria. Technovation, 22(3), 147-159. https://doi.org/10.1016/S0166-4972(00)00081-X

Kee, D.M.H., Effendi, A.A., Talib, L.A.A., \& Rani, N.A.B. (2011). A preliminary study of top SMEs in Malaysia: Key success factor vs government support. Journal of Global Business and Economics, 2(1), 48-58.

Kiatgan, C., \& Almsafir, M.K. (2013). The determinants of SME succession in Malaysia: From entrepreneurship perspective. Journal of Advanced Social Research, 3(12), $350-361$.

Kline, R.B. (2015). Principles and practice of structural equation modelling. New York \& London: The Guilford Press.

Knockaert, M., Vandenbroucke, E., \& Huyghe, A. (2012). Unravelling the need for innovation support services in new technology-based firms: The impact of commercialisation strategy. Science and Public Policy, 40(1), 85-96. https://doi.org/10.1093/scipol/scs060

Lindelöf, P., \& Löfsten, H. (2004). Proximity as a resource base for competitive advantage: University-industry links for technology transfer. The Journal of Technology Transfer, 29(3), 311-326. https://doi.org/10.1023/B:JOTT.0000034125.29979.ae

Lussier, R.N., \& Halabi, C.E. (2010). A three-country comparison of the business success versus failure prediction model. Journal of Small Business Management, 48(3), 360-377. https://doi.org/10.1111/j.1540-627X.2010.00298.x

Lussier, R.N., \& Pfeifer, S. (2001). A cross-national prediction model for business success. Journal of Small Business Management, 39(3), 228-239. https://doi. org/10.1111/0447-2778.00021

McKelvey, M., \& Lassen, A.H. (2013). How entrepreneurs do what they do: Case studies of knowledge-intensive entrepreneurship. Cheltenham: Edward Elgar Publishing. https://doi.org/10.4337/9781781005507

Muhammad, M., Char, A.K., Yasoa, M.R., \& Hassan, Z. (2009). Small and medium enterprises (SMEs) competing in the global business environment: A case of Malaysia. International Business Research, 3(1), 66-75. https://doi.org/10.5539/ ibr.v3n1p66

Ng, H.S., \& Kee D.M.H. (2017). Entrepreneurial SMEs surviving in the era of globalization: Critical success factors. In. S. Sindakis, \& P. Theodorou (Eds.), Global opportunities for entrepreneurial growth: Competition and knowledge dynamics within and across firms (pp. 75-90). United Kingdom: Emerald Publishing Limited. https://doi.org/10.1108/978-1-78714-501-620171007

OECD (Organisation for Economic Co-operation and Development). (2000). Small and medium-sized enterprises: Local strength, global reach. Policy Brief, 1-8.

Omri, A., Frikha, M.A., \& Bouraoui, M.A. (2015). An empirical investigation of factors affecting small business success. Journal of Management and Strategy, 34(9), 1073-1093.

Pettersen, I.B., Aarstad, J., Høvig, Ø.S., \& Tobiassen, A.E. (2015). Business incubation and the network resources of start-ups. Journal of Innovation and Entrepreneurship, 5(7). https://doi.org/10.1186/s13731-016-0038-8 
Pickernell, D., Senyard, J., Jones, P., Gary, P., \& Ramsey, E. (2013). New and young firms entrepreneurship policy and the role of government: Evidence from the federation of small businesses survey. Journal of Small Business and Enterprise Development, 20(2), 358-382. https://doi.org/10.1108/14626001311326770

Saleh, A.S., \& Ndubisi, N.O. (2006). An evaluation of SME development in Malaysia. International Review of Business Research Papers, 2(1), 1-14.

Savlovschi, L.I., \& Robu, N.R. (2011). The role of SMEs in the modern economy. Economia, Seria Management, 14(1), 277-281.

Sharifi, O., \& Hossein, B.K. (2015). Understanding the financing challenges faced by startups in India. International Journal of Science Technology and Management, 4(1), 264-272.

SME Corp. (2014). Malaysia annual report. Retrieved 20 September 2018 from http://www.smecorp.gov.my/index.php/en/resources/2015-12-21-11-07-06/smecorp-malaysia-annual-report/book/63-sme-corp-malaysia-annual-report-2014/4sme-corp-malaysia-annual-report

SME Corp. (2015) SME masterplan. Retrieved 20 September 2018 from http://www. smecorp.gov.my/ index.php/en/resources/2015-12-21-11-07-06/sme-masterplan

SME Corp. (2018) SME development policies and programmes, Chapter 5: SME and entrepreneurship development programmes in 2018. Retrieved 20 September 2018 from http://www.smecorp.gov.my/images/SMEAR/SMEAR2017/ENG/ Chapter5.pdf

Sullivan, D., \& Marvel, M. (2011). How entrepreneurs' knowledge and network ties relate to the number of employees in new SMEs. Journal of Small Business Management, 49(2), 185-206. https://doi.org/10.1111/j.1540-627X.2011.00321.x

Surienty, L., Khoo, T.H., \& Kee., D.M.H. (2011). Occupational safety and health $(\mathrm{OSH})$ in SMEs in Malaysia: A preliminary investigation. Journal of Global Entrepreneurship, 1(1), 65-75.

Temtime, Z.T., \& Pansiri, J. (2004). Small business critical success/failure factors in developing countries: Some evidences from Botswana. American Journal of Applied Sciences, 1(1), 18-25. https://doi.org/10.3844/ajassp.2004.18.25

Tengeh, R.K., \& Choto, P. (2015). The relevance and challenges of business incubators that support survivalist entrepreneurs. Investment Management and Financial Innovations, 12(2), 150-161.

Thirlwall, A.P. (2011). The balance of payments constrained growth models: History and overview. PSL Quarterly Review, 64(259), 307-351.

Weber, A., \& Zulehner, C. (2010). Female hires and the success of start-up firms. The American Economic Review, 100(2), 358-361. https://doi.org/10.1257/aer. 100.2 .358

Willemse, J. (2010). The forum SA. SME failure statistics. Retrieved 20 September 2018 from https://www.theforumsa.co.za/forums/showthread.php/7808-SME-FailureStatistics.

Yaacob, N.M., Mahmood, R., Mat Zin, S., \& Puteh, M. (2014). An investigation of the small business startups performance. Journal of Basic and Applied Scientific Research, 4, 10-17. 
Yankov, B., Ruskov, P., \& Haralampiev, K. (2014). Models and tools for technology startup companies success analysis. Journal Economic Alternatives, 3, 15-24.

Yusuf, J.E. (2010). Making sense of entrepreneurial outcomes measurements in the literature: Suggestions for researchers and policymakers. Journal of Developmental Entrepreneurship, 15(3), 325-344. https://doi.org/10.1142/S1084946710001580

Yusuf, J.E. (2014). Impact of start-up support through guided preparation. Journal of Entrepreneurship and Public Policy, 3(1), 72-95. https://doi.org/10.1108/JEPP01-2012-0004

Zulkifli-Muhammad, M., Char, A.K., Yasoa, M.R., \& Hassan, Z. (2009). Small and medium enterprises (SMEs) competing in the global business environment: A case of Malaysia. International Business Research, 3(1), 66-75. 